\title{
Strongylophthalmyiidae, Tanypezidae and Megamerinidae (Diptera) in the Czech Republic and Slovakia: current state of knowledge
}

\begin{abstract}
Strongylophthalmyiidae, Tanypezidae and Megamerinidae (Diptera) in the Czech Republic and Slovakia: current state of knowledge. - Acta Mus. Siles. Sci. Natur. 65: 1-13, 2016.

Abstract: A review of the occurrence of representatives of the families Strongylophthalmyiidae, Tanypezidae and Megamerinidae (Diptera) in the Czech Republic and Slovakia is presented based on literary data and recently obtained records. Strongylophthalmyia pictipes Frey, 1935 (Strongylophthalmyiidae) is a new addition to the fauna of the Czech Republic. Its record from the Jizerské hory Mts is the second from Central Europe and represents a new southwesternmost distribution limit of the species. Biology, distribution, faunistics in the Czech Republic and Slovakia and importance for nature conservation (with evaluation of degree of jeopardy) are discussed for all species, including also Strongylophthalmyia ustulata (Zetterstedt, 1847), Tanypeza longimana Fallén, 1820 (Tanypezidae) and Megamerina dolium (Fabricius, 1805 (Megamerinidae).
\end{abstract}

Key words: Diptera, Strongylophthalmyiidae, Tanypezidae, Megamerinidae, Strongylophthalmyia pictipes, biology, distribution, Czech Republic, Slovakia

\section{Introduction}

The recent discovery of a second species of the genus Strongylophthalmyia (Strongylophthalmyiidae) in the Czech Republic (see below) stimulated a revision of all available material of the genus from this country as well as from Slovakia. On this occasion also the occurrence of two other acalyptrate families, Tanypezidae and Megamerinidae, represented by single species in Central Europe, has been studied because they both, like Strongylophthalmyiidae, have hitherto been scarcely recorded from the Czech Republic and, particularly, from Slovakia. Therefore, this study is aimed at a summary of all available information (both published and based on newly obtained records) about the occurrence of all species of the three families in these countries.

Formerly, only one species of each of them were known from the Czech Republic and Slovakia, viz. Strongylophthalmyia ustulata (Zetterstedt, 1847), Tanypeza longimana Fallén, 1820 and Megamerina dolium (Fabricius, 1805), as presented in the electronic checklist version 2 (Roháček $(2009 \mathrm{c}, \mathrm{d}, \mathrm{e})$. All published (relatively scarce) records from the above countries are listed below under each of these species. Most of them have been revised during the course of this study but much more additional material has been newly studied. The data obtained from the material examined are discussed for each species as regards the information on the biology, distribution, occurrence within the Czech Republic and Slovakia and degree of jeopardy.

Although only a single species, Strongylophthalmyia pictipes Frey, 1935, is added to the fauna of the Czech Republic, this record is very important, confirming that two species of Strongylophthalmyiidae in fact occur in Central Europe. S. pictipes can be easily recognized from its more common congener, $S$. ustulata, in having wing with more distinct dark apical spot, all femora (fore femora only dorsally) dark in apical third to half, also tibiae largely darkened (Figs 1, 3, compare with Fig. 4) and broad, short and blackish palpus. For other differences see Palazcyk et al. (2013). 


\section{Material and methods}

All available material of flies of the families Strongylophthalmyiidae, Tanypezidae and Megamerinidae from the Czech Republic and Slovakia has been examined. It is deposited in various collections as follows: BMSC - Blatské muzeum v Soběslavi, Czech Republic, JMB - collection of Dr. Jan Máca, Ph.D., České Budějovice; KMVC - Museum of East Bohemia, Hradec Králové, Czech Republic; MBP - collection of Prof. Dr. Miroslav Barták, CSc., Praha; NMPC - National Museum, Praha; SMLC - Severočeské muzeum, Liberec; SMOC - Silesian Museum, Opava, Czech Republic. Revised literary records are indicated by ,!“ in parantheses behind the date of the respective reference.

Specimens have been examined using two types of binocular stereoscopic microscopes (Reichert, Olympus). When necessary male genitalia and female terminalia were examined after detachment, treating in hot $10 \% \mathrm{KOH}$, washing in water and dissection of the whole abdomen in a drop of glycerine under a binocular microscope. After examination, all parts were transferred to a small plastic tube in glycerine and pinned below the respective specimens. Some of the collected adults were retained alive in plastic tubes to be photographed shortly after being captured in special boxes by means of a digital camera Canon EOS 60D with a macro lens (Canon MP-E $65 \mathrm{~mm} \mathrm{1-5 \times )} \mathrm{and} \mathrm{ring} \mathrm{macro} \mathrm{flash} \mathrm{(Canon} \mathrm{MR-14EX).}$

\section{Results}

\section{STRONGYLOPHTHALMYIIDAE}

\section{Strongylophthalmyia pictipes Frey, 1935 (Figs 1, 3)}

Material examined: CZECH REPUBLIC: N Bohemia: Jizerské hory Mts, Horní Maxov-Malá Strana res., $50^{\circ} 45^{\prime} 58^{\prime \prime} \mathrm{N}, 15^{\circ} 12^{\prime} 04^{\prime \prime} \mathrm{E}, 715 \mathrm{~m}$, netted from fallen birch trunks, 15.vii.2015, 10̂, J. Roháček leg. (SMOC, photographed).

Biology: Krivosheina (1981) reported on specimens of S. pictipes reared by Babushkin from larvae found under the bark of rotting aspen in Russia (Buryatia) but the immatures remain undescribed. In SE Poland (Bieszczady Mts: Terebowiec valley) a total of 12 adults (all males) of this species were collected in wet deciduous forest (Alnetum incanae) on a dead trunk of aspen (Populus tremula) lying on the ground near a stream from 29 June to 3 August (Palazcyk et al. 2013). However, the only male found in the Jizerské hory Mts (N Bohemia) was swept from fallen dead trunks of a birch (Betula sp.) on the ground in a humid mixed forest (Fig. 2).

Distribution: This little known species seems to be widespread largely in the northern belt of the Palaearctic Region, see Palazcyk et al. (2013). According to the catalogue presented by the latter authors, S. pictipes is known from the following countries: Norway, Sweden, Finland, Poland, Russia: Moscow region, Buryatia, Amur district. The only previous record from Central Europe originates from Poland (Bieszczady Mts), and, consequently, the first finding from the Czech Republic (see above) is not only the second from Central Europe but it also represents a new southwestern distribution limit of this species.

Discussion: Based on Polish record from the Bieszczady Mts, Palazcyk et al. (2013) discussed $S$. pictipes as a Boreomontane species having in this Carpathian locality a relict population possibly of the Late-Pleistocene (Alleröd) or Early-Holocene (Preboreal) origin. The single record from the Jizerské hory Mts also indicates that S. pictipes occurs very locally in montane forested habitats of Central Europe and, hence, corroborates its Boreomontane distribution in Europe. Judging from its relict distribution, S. pictipes is surely the most endangered species (of all here discussed taxa) not only in the Czech Republic but in the whole of Central Europe.

\section{Strongylophthalmyia ustulata (Zetterstedt, 1847) (Fig. 4)}

Material examined: CZECH REPUBLIC: S Bohemia: Kašperské Hory 2 km SW, nr. Losenice, 49.08 N / 13.33 E, 600 m, 9.vii.1994, 1 q, M. Barták leg. (V. Martinek det. 1994, KMVC); Šumava Mts, Malá niva, 49.08' N 13.33' E, peat-bog, Malaise trap, 1ㅇ, M. Barták \& J. Roháček leg. (SMOC). N Bohemia: Josefův Důl, Jedlový důl res., sweeping, 12.vii.2005, 1엉. J. Preisler leg. (JMB); Jizerské hory Mts, Josefův Důl, Jedlový důl res., 

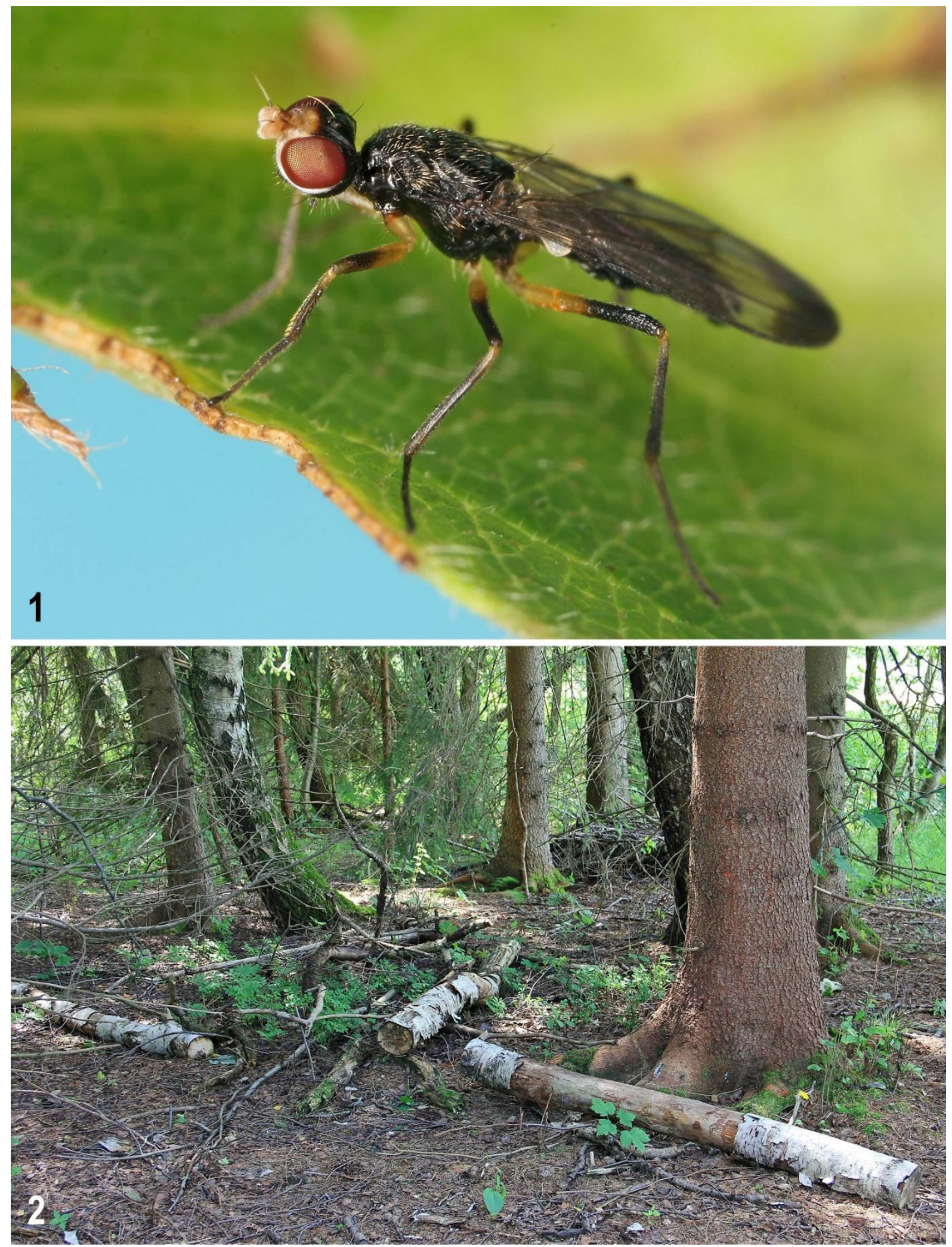

Figs 1-2: Strongylophthalmyia pictipes Frey and its habitat in the Czech Republic. 1 - living male (in sublateral view) from Horní Maxov-Malá Strana res. (Czech Republic: Jizerské hory Mts); 2 - habitat with rotting birch trunks where this specimen was collected. Photo by J. Roháček. 
5047'24"N, 15¹4'29"E, 700 m, sweeping vegetation along brook, 21.vii.2013, 19, 15.vii.2015, 2 9 , J. Roháček leg. (SMOC, 19 photographed); Jizerské hory Mts, Kořenov, Jizera river, 5046'18.3"N, 15²2'56.2"E, $640 \mathrm{~m}$, sweeping and individual coll. on river banks, 24.vii.2013, 3 ; Jizerské hory Mts, Kořenov, Jizerka, Bukovec NR, Starý lom, 5048'44"N, 15²1'39.9"E, 925 m, sweeping undergrowth, 20.vii.2015, 19, all M. Tkoč leg. (NMPC); Jizerské hory Mts, Rejdice, potok Ješkrabec (5258), 650 m, emergent trap, 16.viii.-1.9.2015, 1, J. Preisler \& P. Vonička leg. (SMLC); Holany env. (5352), distr. Česká Lípa, sweeping, 19.vii.2006, 10̃, J. Preisler leg. (coll. MBP). E Bohemia: Orlické hory Mts, Popelov, L břeh Zdobnice, 1.vii.1982, 1 ( (J. Roháček det. 1984); Orlické hory Mts, Pěčín, valley of Zdobnice (5864), 440 m, 13.vii.1995, 19, B. Mocek leg.; Sněžné v Orlických horách, 21.viii.1965, 19, V. Martinek leg. (and det. 1991); Železné hory Mts, TřemošniceHedvikovské údolí (6159), 29.vii.1994, 19, B. Mocek leg. (V. Martinek det. 1997) (all in KMVC). S Moravia: Soutok, Ranšpurk res. (distr. Břeclav), sweeping undergrowth of deciduous forest, 14.vi.2000, 19, J. Roháček leg. (SMOC); Bílé Karpaty Mts, Štítná-Žírce, 49²'46-56"N, 1759'6-20"E, 400-450 m, mass sweeping, 4.viii.2013, 1ठ̊; S Moravia: Bílé Karpaty Mts, Štítná, „U brodu“, 19.vii.2015, 1 +, both M. Tkoč leg. (NMPC). N Moravia: Karlova Pláň-Karlovec (distr. Bruntál), sweeping undergrowth of alder forest, 30.vi.1987, 1 , 5.viii.1987, 19; Deštné env., Kamenná hora Mt. env. (distr. Opava), sweeping undergrowth of deciduous forest, 27.vi.1996, 19; Hněvošice, Hněvošický háj res. (distr. Opava), sweeping undergrowth of deciduous forest, 29.vi.1995, 1q; Hradec nad Moravicí-Záviliší, sweeping undergrowth of mixed forest, 26.vi.1994, 2ో; N Moravia: Moravskoslezské Beskydy Mts, Dolní Bečva-Horní Rozpité, sweeping undergrowth of mixed forest, 30.vi.1994, 1q, all J. Roháček leg. (SMOC).

SLOVAKIA: C Slovakia: Pol'ana Mts, Čierny Potok valley, sweeping undergrowth of alder forest, 8.vii.2000, 1§̂; Pol'ana Mts, Hrončecký grúň, sweeping undergrowth of mixed forest, 12.vi.1999, 1 , , on rotting tree trunks, 4.vii.2000, 1 ; Pol’ana Mts, Spády waterfall, sweeping vegetation along brook, 4.vii.2000, 1 , all J. Roháček leg (SMOC). E Slovakia: Hostovické louky res. (distr. Humenné), sweeping undergrowth of deciduous forest, 16.vi.1986, 1q; Stakčín env. (Chotinka valley) (distr. Humenné), sweeping undergrowth of deciduous forest, 20.vi.1986, $3 \delta^{\lambda} 1$ + ; Ruský Potok env. (distr. Humenné), sweeping undergrowth of alder forest, 11.vii.1993, $1{ }^{\top}$; Nová Sedlica env., Stužica res., sweeping undergrowth of mixed forest, 18.vi.1986, 2ᄋ; Vihorlat Mts, Hypkanina nr. Motrogon, 850 m, sweeping undergrowth of deciduous forest, 15.vi.1986, 19, all J. Roháček leg. (SMOC).

Comparative material examined: ROMANIA: E Romania: Calimani Mts, $15 \mathrm{~km} \mathrm{~N}$ Lunca Bradului, 11.vii.1988, 1ㅇ, B. Mocek leg. (KMVC, V. Martinek det. 1992). SWEDEN: Stockholm, Norra Djurgården,

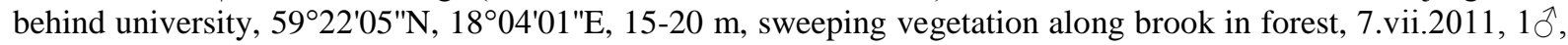
J. Roháček leg. (SMOC).

Published records: CZECH REPUBLIC: Bohemia: Šumava Mts-Malá Niva (Roháček \& Barták 1999!); Janov nad Nisou (Martinek 1985b); Orlické hory Mts-Sedloňov (Martinek 1967; Cole 1981); Orlické hory MtsPopelov (Roháček 1985!). Moravia: Vranov nad Dyjí (Czižek 1910, as Chyliza); Lednice-Horní les (Vaňhara 1981, 1986) - note: Vaňhara (1981) listed „Strongylophthalmyia aenea Zett.“ in addition to S. ustulata but it is an error inasmuch as no such species exists; Karlova Plán̆-Karlovec, Hradec nad Moravicí-Záviliší, Moravskoslezské Beskydy Mts-Horní Rozpité (Roháček 1995c!).

SLOVAKIA: Hostovické lúky res., Vihorlat Mts-Hypkanina pod Motrogonem res., Stakčín-Chotinka, Nová Sedlice-Stužica res. (Roháček 1987!); Ruský Potok (Roháček 1995a!); Pol'ana Mts-Čierny Potok, Pol’ana MtsHrončecký grúň res., Pol’ana Mts-Spády waterfall (Roháček 2009a!).

Biology: Similarly to other species of the genus (see Barber 2006) S. ustulata is known to develop under bark of dead trunks of deciduous trees. Krivosheina (1981) commented upon specimens reared from larvae from under the bark of aspen in various parts of Russia. Close association of larvae with wet decaying cambium under bark of aspen (Populus tremula) was also confirmed by repeated rearings in Britain (see Rotheray \& Robertson 1998; Rotheray 2015). Description of mature larva of $S$. ustulata (including anterior and posterior spiracle and cephalopharyngeal skeleton was given by Mamaev et al. (1977) and the puparium was described by Rotheray \& Robertson (1998).

In contrast to $S$. pictipes, adults of $S$. ustulata can usually be found on larger leaves in undergrowth of wet forests (Shatalkin 1993; Palazcyk et al. 2013). This is in accordance with my experience. The humid deciduous or mixed forests with an aspen component, particularly those surrounding brooks or rivers at submontane to montane altitudes seem to be the preferred habitats of this species. In lowlands $S$. ustulata proved to be restricted to colder places shadowed by dense canopies or by steep slopes of valleys and ravines. In the Czech 

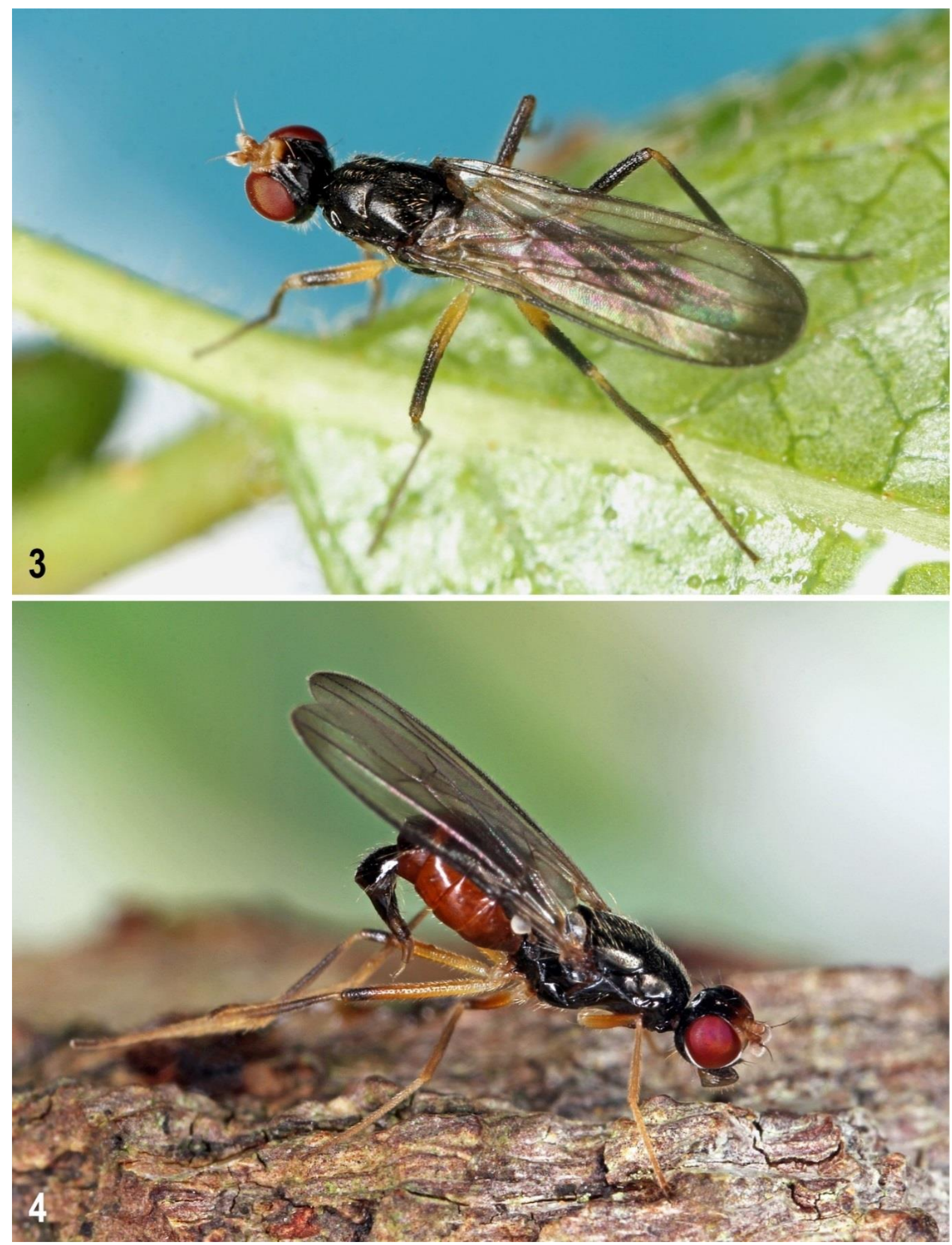

Figs 3-4: Strongylophthalmyia species. 3 - male S. pictipes Frey, same specimen as in Fig. 1 (in dorsal view); 4 - female $S$. ustulata (Zetterstedt) (in lateral view) from Jedlový důl res. (Czech Republic: Jizerské hory Mts); it was photographed immediately after it had been cleaning its postabdomen, using its hind legs, hence the pose with its postabdomen exposed and its hind legs crossed. Photo by J. Roháček. 
Republic and Slovakia adults have been found from 15 June to 21 August (not to mention a Malaise trapped specimen from 16 August-1 September) which agrees perfectly with the flight span recorded by Palazcyk et al. (2013) in Poland.

Distribution: Transpalaearctic, widespread in temperate belt of the region. Following Palazcyk et al. (2013, see here for relevant references) it was recorded from Andorra, Great Britain, Germany, Switzerland, Austria, Czech Republic, Slovakia, Hungary, Poland, Ukraine, Romania, Norway, Sweden, Finland, Latvia, Estonia, Russia (CET, NET, Buryatia, FE), Japan and North Korea. Judging from the above records (both published and presented here) from the Czech Republic and Slovakia it seems to be a rather uncommon and local species here, being hitherto unrecorded from some (particularly lowland) regions of both countries (e.g. central Bohemia, western and southern Slovakia).

Discussion: $S$. ustulata seems to primarily be a species of the temperate zone of deciduous forests, thus occurring more southerly than $S$. pictipes but clearly absent in arid southern areas of both Europe and Asia. In contrast to Tanypeza longimana and Megamerina dolium, no species of Strongylophthalmyia has hitherto not been treated as threatened in the Czech Republic but $S$. ustulata was listed as a data deficient (DD) species in Slovakia (Jedlička \& Stloukalová 2001). However, based on here recorded data, S. ustulata proved to be a rarer, more local and more habitat dependent species than Tanypeza longimana and Megamerina dolium (at least in the Czech Republic) therefore it should be classified as a vulnerable (VU) or as a notable (NT) species in both countries.

\section{TANYPEZIDAE}

\section{Tanypeza longimana Fallén, 1820 (Fig. 5)}

Material examined: CZECH REPUBLIC: S Bohemia: Kašperské Hory $2 \mathrm{~km} \mathrm{SW,} \mathrm{nr.} \mathrm{Losenice,} 49^{\circ} 08^{\prime} \mathrm{N}$, 13³3'E, 600 m, 9.vii.1994, 19, M. Barták leg.; České Budějovice env., Švábův Hrádek, 4858'47"N, $14^{\circ} 29^{\prime} 27^{\prime \prime E}$, yellow (pan) trap, 13.vi.2002, 19, J. Olejníček leg.; Vráž nr Písek, 49²4'12"N, 1407'13"E, 430 m, damp meadow,18.-22.vi.2007, $1^{\circledR} 2$ \%, 16.-20.vi.2008, 1 \%; 49 $24^{\prime} 01^{\prime \prime} \mathrm{N}, 1^{\circ} 07^{\prime} 02^{\prime \prime} \mathrm{E}, 400 \mathrm{~m}$, meadow+wood, 20.26.vi.2009, 4q, 19.-25.vi.2010, 1 \%; 49² $24^{\prime} 12^{\prime \prime} \mathrm{N}, 14^{\circ} 06^{\prime} 57^{\prime \prime} \mathrm{E}, 400 \mathrm{~m}$, pyramidal trap in wood, 24.vi.-19.vii.2010, 3 ; $49^{\circ} 24^{\prime} \mathrm{N}, 14^{\circ} 07-08^{\prime} \mathrm{E}, 400 \mathrm{~m}$, meadow, aromata pan trap, 18.-24.vi.2011, 1q, all M. Barták leg. (MBP); Vráž nr Písek, Novovrážský pond, sweeping, 13.-16.vi.2009, 1ठ1, J. Preisler leg. (SMLC); S Bohemia: Řečice-Sádky $0.5 \mathrm{~km} \mathrm{SW}$, Hadrava pond, 4908'56"N, 15³1'38"E, $600 \mathrm{~m}$, on pond shore vegetation, 7.vii.2015, 1 ㅇ, J. Roháček leg. (SMOC, photographed). C Bohemia: Sázava $5 \mathrm{~km} \mathrm{~N}, 49^{\circ} 55^{\prime} \mathrm{N}, 14^{\circ} 55^{\prime} \mathrm{E}$, damp meadow, 16.vi.1990, 1 q, M. Barták leg. (MBP). N Bohemia: Duchcov 4 km E (4), 50³7'N, 1341'E, 275 m, oak wood, 16.vii.1992, 1ㅇ, M. Barták leg. (MBP); Meandry Smědé res. nr Černousy, rybník Dubák (5056), sweeping, 1웅 Jizerské hory Mts, Bílý Potok, small ponds NE from railway station, sweeping, 15.vi.2012, 19, both J. Preisler leg. (SMLC); Jizerské hory Mts, Kořenov 1.8 km NE, Jizera river, 5046'19"N, 15²2'55"E, 640 m, sweeping riverside vegetation, 13.vi.2012, $3{ }^{\lambda} 6+$ (some photographed); Jizerské hory Mts, Horní Maxov-Malá Strana res., $50^{\circ} 45^{\prime} 58^{\prime \prime} \mathrm{N}, 15^{\circ} 12^{\prime} 04^{\prime \prime} \mathrm{E}, 715 \mathrm{~m}$, netted above fallen birch trunks, 15.vii.2015, 1우, all J. Roháček leg. (SMOC); same locality, 15.vii.2015, 19, M. Tkoč leg. (NMPC); N Bohemia: Krkonoše Mts, Zrcadlový potok, 50³8'01.9"N, 1443'54.6"E, Malaise trap, 30.vi.-4.viii.2009, 1ㅇ․ J. Vaněk leg. (MBP). E Bohemia: NPR Bohdanečský rybník a rybník Matka (5959.60), 5.vii.2004, 1ð̄, B. Mocek leg. (MBP). S Moravia: Podyjí NP,

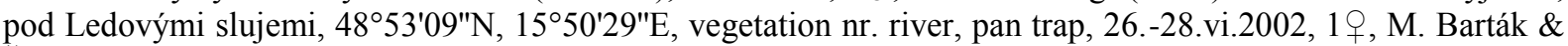
Š. Kubík leg. (MBP); Lednice-Pastvisko, nr horse pasture, sweeping undergrowth of deciduous forest, 12.vi.2000, 1 ; Soutok, Cahnov res. (distr. Břeclav), sweeping undergrowth of deciduous forest, 28.v.1998, $1 \delta^{\lambda}$, both J. Roháček leg. (SMOC); Chřiby Mts, Salaš, Salašský potok, 4909'07.5"N, 17019'05.4"E, 330 m, sweeping vegetation along brook, 6.viii.2012, 1ठ1; Bílé Karpaty Mts, Javorník, Filipovské údolí, 4850'34.2"N, 17³3'45.5"E, $400 \mathrm{~m}$, sweeping undergrowth close to Hrubý potok stream, 3.vii.2013, 1§, both M. Tkoč leg. (NMPC). N Moravia: Nový Jičín-Kunín, nr. Odra (river), sweeping undergrowth of deciduous forest, 24.vi.1988, 1+; Moravskoslezské Beskydy Mts, Dolní Bečva-Horní Rozpité, sweeping undergrowth of mixed forest, 30.vi.1994, 29, all J. Roháček leg. (SMOC); Horní Lomná 3 km N, 49³3'N, 1840'E, 520 m, meadow nr brook, 20.vi.1986, 1 , , M. Barták leg. (MBP).

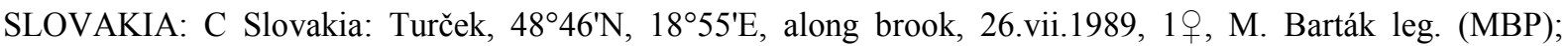
Muránska planina NP, Suché doly res. (Teplica), 16.vii.2014, 1ð̃, M. Tkoč leg. (NMPC). E Slovakia: Malé 

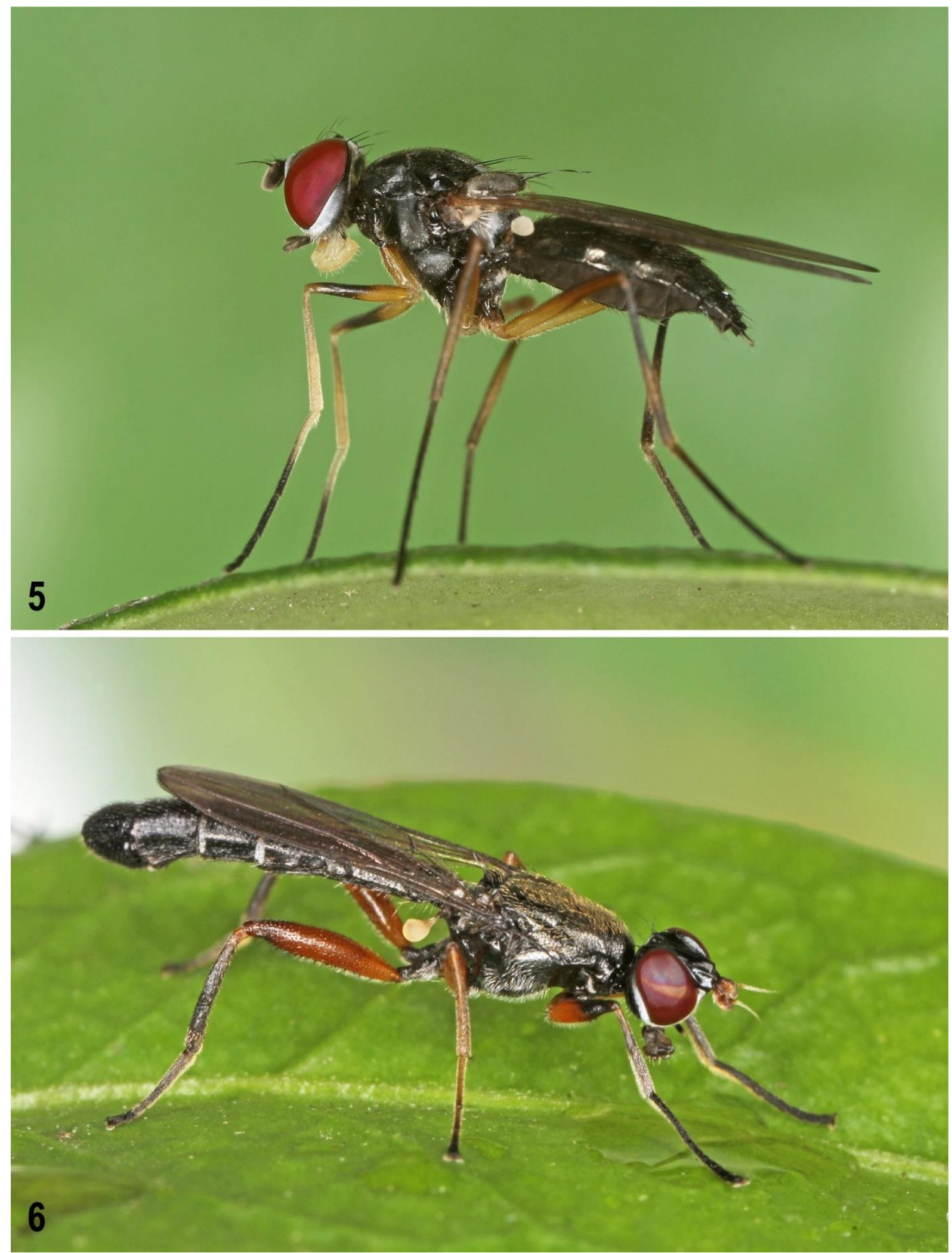

Figs 5-6: Species of Tanypezidae and Megamerinidae. 5 - female Tanypeza longimana Fallén (in lateral view) from shore of Hadrava pond (Czech Republic: Ǩečice-Sádky env.); 6 - male Megamerina dolium (Fabricius) (in sublateral view) from Hulišstata res. (Czech Republic: Kostelní Myslová env.). Photo by J. Roháček. 
Trakany nr. Tisa river, sweeping undergrowth of floodplain deciduous forest, 15.v.1987, 1ð̂, 2.vi.1988, 1 , 4.vi.1988, 7ð゙4우, all J. Roháček leg. (SMOC).

Comparative material examined: RUSSIA (CET): Zvenigorod, 55² $43^{\prime} \mathrm{N}, 36^{\circ} 54^{\prime} \mathrm{E}, 130 \mathrm{~m}$, along river, 30.v.1989, 2ð1웅. Marták leg. (MBP).

Published records: CZECH REPUBLIC: Bohemia: no locality (Kowarz 1894), Lysá nad Labem (Vimmer 1913), Dubina forest nr. Osek (Barták 2001a), Vráž nr. Písek (Barták \& Kubík 2013!). Moravia: Adamov (Czižek 1910), Lednice-Horní les (Vaňhara 1981, 1986), Nový Jičín-Kunín, Moravskoslezské Beskydy MtsHorní Rozpité, Horní Lomná (Roháček 1995c!), Soutok-confluence of Morava and Dyje river, Soutok-Cahnov res. (Roháček 1999!), Podyjí NP-Ledové sluje (Barták \& Kubík 2005a!).

SLOVAKIA: Oravský Podzámok (Soós 1946).

Biology: This is the only representative of the family Tanypezidae in the Palaearctic Region (Roháček 1998; Lonsdale 2013). Its biology is insufficiently known, inasmuch as the larvae have hitherto not been found in their natural breeding substrate. It was speculated that larvae may be saproxylic, developing in rotting wood (Chandler 1975) because adults can often been seen on vegetation near decaying stumps or dead fallen trunks (Chandler /l. c./ found them among vegetation growing over a rotten willow). This fact seems to be also indicated by specimens caught by means of pyramidal trap (see material examined) under which a lot of rotting wood was installed. Larvae of $T$. longimana were reared by Foote (1970) on decaying watermelon rind from eggs laid by a gravid female but they failed to pupariate, hence this alternate substrate was probably unsuitable to complete their life history. Foote (1. c.) described only larval instars obtained from the above rearing experiment; the puparium remains unknown. Adults of both sexes often walk on leaves of low vegetation, where also mating can be seen. Margins of moist deciduous or mixed forests, and particularly forested banks of rivers and brooks at lower altitudes seem to be the preferred habitats of this species in Central Europe (Roháček 1998, material examined). Adults were found from 28 May to 6 August in the Czech Republic and Slovakia, while the majority of records are from June.

Distribution: A widespread Holarctic species, largely occurring in the temperate belt of the region. In Europe it is known from Andorra, Great Britain, France, Italy (including Sardinia and Sicily), Germany, Switzerland, Austria, Czech Republic, Slovakia, Hungary, Bosnia-Herzegovina, Romania, Poland, Ukraine, Denmark, Norway, Sweden, Finland, Russia (CET, NET, SET), see Roháček (2013). For distribution in other parts of the Palaearctic and Nearctic Regions see the catalogue by Lonsdale (2014). In the Czech Republic (cf. above records) it seems to be an uncommon species with a scattered occurrence throughout the country, ranging from lowlands (most records) to submontane altitudes (no record above 750 m). Surprisingly, in Slovakia there has been only a single published record (Soós 1946, repeated by Roháček 1986) and also the unpublished records (see material examined) are scarce, from only 3 localities. Consequently, T. longimana appears to be rare in Slovakia which could be due to the largely montane landscape in this country.

Discussion: Like $S$. ustulata (see above) also T. longimana is obviously a component of the fauna of the zone of deciduous forests but, in contrast to the former species, it expanded its distribution also more southerly, e.g. to some Submediterranean or even Mediterranean areas of Europe. In the Czech Republic T. longimana is considered to be a vulnerable (VU) species by Roháček (2005a). Its habitat dependence and frequency in suitable ecosystems in the Czech Republic is almost comparable to those of S. ustulata, so it also is similarly threatened in the country. In Slovakia, on the contrary, T. ustulata seems to be much rarer and, therefore, its status of jeopardy, should be there higher. 


\section{MEGAMERINIDAE}

\section{Megamerina dolium (Fabricius, 1805) (Fig. 6)}

Material examined: CZECH REPUBLIC: S Bohemia: Soběslav-okolí, 5.viii.8.1978, 1ठ, V. Karas leg. (BMSC); Temelín, 49 $10^{\prime} 54^{\prime \prime} \mathrm{N}, 14^{\circ} 23^{\prime} 10^{\prime \prime} \mathrm{E}, 510 \mathrm{~m}$, atomic power station, wetland, Malaise trap, 1.vii.13.ix.2007, 1엉. J. Farkač leg. (MBP); Vráž nr Písek, 49²4'13"N, 1407'15"E, 400 m, damp meadow, vi.2001, 1 ; ; same locality, $49^{\circ} 24^{\prime} 08^{\prime \prime} \mathrm{N}, 1^{\circ} 07^{\prime} 08^{\prime \prime} \mathrm{E}, 430 \mathrm{~m}$, alder forest, Malaise trap, 18.vii.-22.viii.2008, 10, 24.v.24.vi.2010, 1 \%; same locality, $49^{\circ} 24^{\prime} 06^{\prime \prime} \mathrm{N}, 1^{\circ} 07^{\prime} 08^{\prime \prime} \mathrm{E}, 400 \mathrm{~m}$, alder wood, Malaise trap, 18.vi.-18.vii.2009, 2 \%; same locality, $49^{\circ} 24^{\prime} 01^{\prime \prime} \mathrm{N}, 1^{\circ} 07^{\prime} 02^{\prime \prime} \mathrm{E}, 400 \mathrm{~m}$, meadow+wood, 19.-25.vi.2010, 2ᄋ; same locality, 49 $24^{\prime} 12^{\prime \prime} \mathrm{N}$,

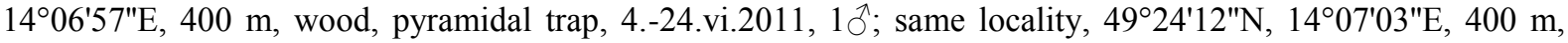
wood, pyramidal trap, 12.vi.-10.ix.2012, 1ㅇ, all M. Barták leg. (MBP). C Bohemia: Bučiny, Skryje env., 13.vii.1977, 1ð̃, V. Martinek leg. (KMVC, V. Martinek det. 1991); Hradčany, PP Báň (5857b), Malaise trap, 9.30.vii.2003, $1 \mathrm{\delta}^{\top} 1$ ㅇ, B. Mocek leg. (KMVC); Velké Popovice $2 \mathrm{~km} \mathrm{~S}, 49^{\circ} 54^{\prime} \mathrm{N}, 1^{\circ} 39^{\prime} \mathrm{E}, 470 \mathrm{~m}$, edge of wood, 10.vii.1988, 1ð̂, M. Barták leg. (MBP); Podolia (= ?? Praha-Podolí), no date, $1 \hat{\jmath} 1$, , R. M. Hanus leg.; Houška, vi. $1 \jmath^{\lambda} 1$; Kolín, no date, $1 \jmath^{\lambda}$, both Wimmer leg. (all NMPC); Dymokury, 25.vii.1961, $1 \overbrace{}^{\lambda} 1$, V. Zeman leg. (SMOC). N Bohemia: České Švýcarsko NP, Křinice, nr Brtnický brook, Malaise trap, 20.vii.2009, 1 , Trýzna leg. (NMPC); Chomutov, Březenská rokle, vnitřní plocha, pan trap, 24.-26.vi.2001, 1q, Bartáková leg.; Březno nr Chomutov, nr Hutná brook, 50²4'24"N, 1323'21"E, 285 m, Malaise trap, 5.vi.-17.vii.1999, 10, 27.v.-

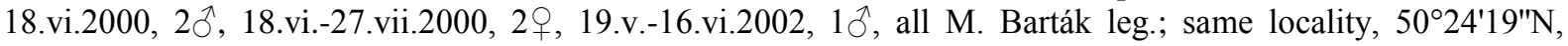
$13^{\circ} 23^{\prime} 34^{\prime \prime E}$, pan trap (VP), 14.-16.vi.2002, 1q, Bartáková leg. (all MBP); Bílina-Holibka, 50³1'21"N, 134'47"E, 420 m, Malaise trap, 28.v.-15.vi.1998, 2ㅇ, 15.vi.-23.vii.1998, 3ㅇ, 24.vii.-24.viii.1998, 1; BílinaŠtěpánov, 50³1'59"N, 1351'39"E, $380 \mathrm{~m}$, mixed wood nr brook, Malaise trap, 28.v.-15.vi.1998, 1울. 15.-

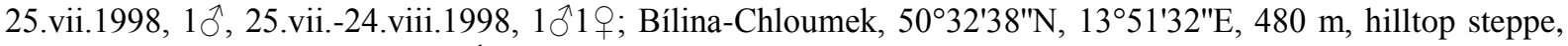

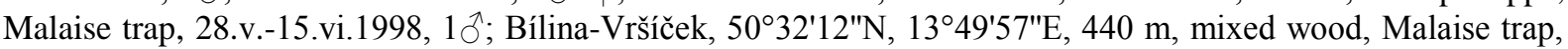

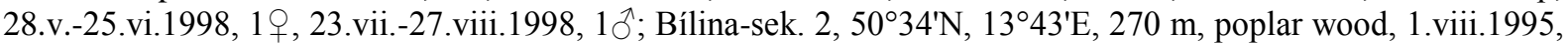

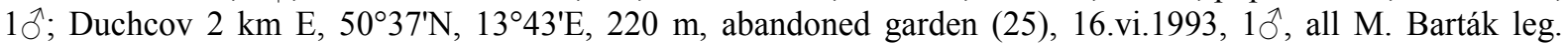

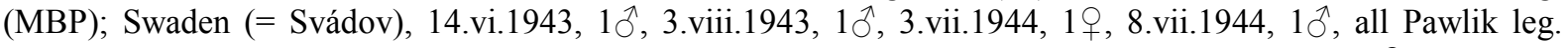
(NMPC). E Bohemia: Polabská nížina, Nový Hradec Králové (5860), mixed forest, 16.vi.1995, 19, B. Mocek leg. (KMVC, V. Martinek det. 1998); Hradec Králové (5760c), 20.vi.2013, 1ㅇ, 21.vii.2013, 1q, 24.vii.2013, 1 Ĵ, V. Zeman leg. (KMVC). SW Moravia: Třešt', Klučí res. (distr. Jihlava), on rotting tree trunks, 12.vii.1995,

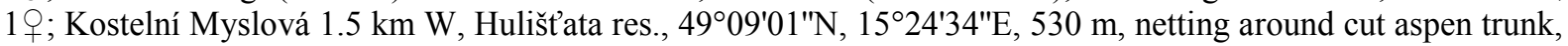

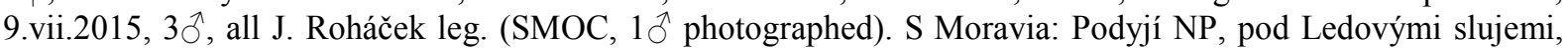
$48^{\circ} 53^{\prime} 09^{\prime \prime} \mathrm{N}, 15^{\circ} 50^{\prime} 29^{\prime \prime} \mathrm{E}$, wetland nr river, pan trap, 31.v.-2.vi.2002, 1 9 ; same locality, lowland wood, Malaise

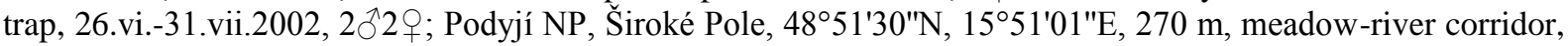

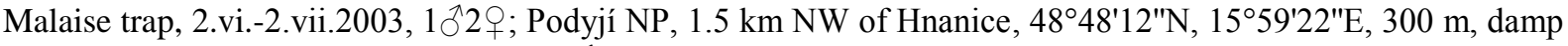

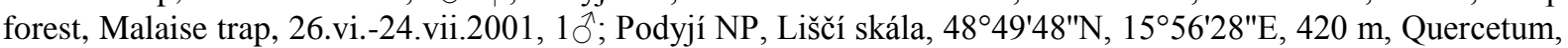

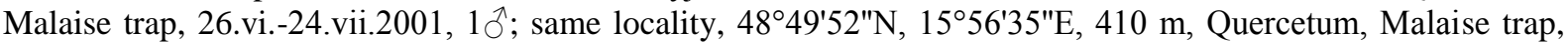

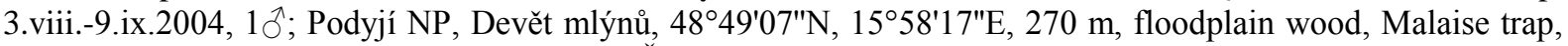
2.vii.-3.viii.2004, 19; S Moravia: Podyjí NP, Č́́žovský rybník, 4852'55"N, 1553'11"E, 380 m, meat-baited ET, 3.viii.-9.ix.2004, 19, all M. Barták \& Š. Kubík leg. (MBP); Soutok, Cahnov res. (distr. Břeclav), sweeping undergrowth of deciduous forest, 28.v.1998, 1ठ̂, J. Roháček leg. (SMOC); Bílé Karpaty Mts, Kůtky res., Malaise trap, 26.vi.2008, 1 q, Chvojka, Ježek \& Macek leg. (NMPC); C Moravia: Grygov, 12.vi.1954, $1 \delta^{\lambda} 1$, J. Palásek leg. (KMVC). N Moravia: Karviná-Doly, Mokroš, 4949'16"N, 18²9'35"E, 255 m, sweeping, deciduous

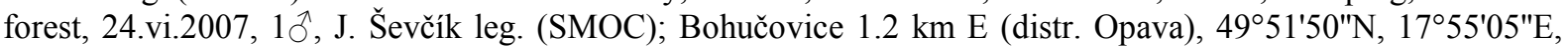
470 m, on freshly cut aspen wood, 7.vii.2013, 1§, J. Roháček leg. (SMOC, photographed).

SLOVAKIA: S Slovakia: Kováčov, P.t. údolie, 4.vi.1974, 1ठ̋’; Chl’aba, P.t., 14.vi.1977, 1q, J. Čepelák leg. (KMVC); Kováčovské kopce Mts, Kováčov nr. Štúrovo, sweeping undergrowth of deciduous forest, 18.vii.1983, $1{ }^{\lambda} 2$, , J. Roháček leg. (SMOC). C Slovakia: Hriňová-Dolná Riečka, on cut aspen wood, 17.vi.2009, 9ð̄, J. Roháček leg. (SMOC). N Slovakia: Belianske Tatry Mts, Javorina, 25.vii.1961, 3ð̊, V. Zeman leg. (KMVC, J. Roháček det. 1982). E Slovakia: Slovenský kras, Slavec nr. Plešivec, on decayed vegetation, 31.viii.1980, 1ठ;; Stakčín env. (Chotinka valley) (distr. Humenné), sweeping undergrowth of deciduous forest, 22.vi.1983, $6 \hat{O}$, all J. Roháček leg. (SMOC)

Published records: CZECH REPUBLIC: Bohemia: Beroun env. (Weinfurter 1907, as Lissa loxocerina) Dymokury, Nový Hradec Králové, Hradec Králové, Holovousy (Roháček 1985!); Bučiny u Skryjí (Martinek 1989!); Pokrok nr. Osek, Dubina forest nr. Osek, Štěpánov nr. Bílina, Venuše nr. Braňany, Holibka nr. Bílina (Barták 2001b!); Vráž nr. Písek (Barták \& Kubík 2013!). Moravia: Kamenný Mlýn (Landrock 1907: Steinmühle); Štípa nr. Zlín (Martinek 1979); Lednice-Horní les (Vaňhara 1981, 1986; Roháček 1999!); ZnojmoÚnanov pond, Mikulov-Turold (Martinek 1985a); Drnholec-Brodský les (Rozkošný \& Vaňhara 1992, 1994); 
Brno-Hády (Rozkošný \& Vaňhara 1993); Soutok-Cahnov res. (Roháček 1999!); Podyjí NP-Hnanice, Liščí skála, Ledové sluje, Široká pole, Devět Mlýnů, Čižovský rybník (Barták \& Kubík 2005b!)

SLOVAKIA: Slovenské Nové Město (Kowarz 1883); Kováčovské kopce Mts-Kováčov, Slavec nr. Plešivec, Stakčín-Chotinka (Roháček 1985!); Hriňová-Dolná Riečka (Roháček 2009b!).

Biology: This only European representative of Megamerinidae is known to mainly occur in deciduous forest. Adults are attracted to freshly cut wood, particularly aspen, poplar and oak. The larva was first found under bark of a fallen oak in Germany by Hennig (1943), who considered it predatory on other subcortical insect larvae due to the formation of its cephalopharyngeal skeleton. Krivosheina \& Krivosheina (1997) observed that larvae of $M$. doli-um usually attack damaged or slow saprophagous or saproxylic larvae living under bark and recorded them from under bark of dead trunks of aspen (most frequently), poplar, willow and oak. The first description of the larva was given by Krivosheina \& Mamaev (1967); a more detailed treatment and illustrations were presented by Krivosheina \& Krivosheina (1997). The data obtained from the specimens collected in the Czech Republic and Slovakia confirm association of adults with cut or fallen trunks of aspen in particular. More interestingly, the species proved to live in various types of deciduous and mixed forest types including young and damaged ones, so indicating a formerly unrecorded habitat tolerance. In countries under study adults were captured from 24 May to 18 September (based on records from Malaise traps); they seem to most frequently occur in June-August.

Distribution: Megamerina dolium is a transpalaearctic species, also associated with the temperate belt (preferably in the zone of deciduous forests). In Europe there are records from Great Britain, France, Germany, Italy, Switzerland, Austria, Hungary, Czech Republic, Slovakia, Poland, Denmark, Sweden, Finland, Ukraine, Russia (NET) (see Ozerov 2013). In the Asian part of the Palaearctic Region it is known from Russia: Ossetia, Altai, Tuva, Buryatia and Far East (Amur region and southern Primorye), see Krivosheina et al. (1996). In the Czech Republic there are rather numerous records distributed in all parts of the country, from lowland to submontane altitudes. This is also true for Slovakia despite the finds there being less frequent.

Discussion: The species can be found relatively frequently in both countries under study provided it is searched for in woodland with cut aspen trunks or taken by rearing from dead aspen (poplar, oak or other deciduous) wood, e.g. in pyramidal or emergence traps. This fact indicates that its former classification as a vulnerable (VU) species in the Czech Republic (Roháček 2005b) has obviously been overvalued due to insufficient information about its habitat association. It can now be proposed to treat it as a notable (NT) species at most.

Acknowledgements: It is an agreeable duty to express my sincere gratitude to M. Barták, (Praha, Czech Republic), J. Máca (České Budějovice, Czech Republic), B. Mocek (Hradec Králové, Czech Republic), J. Preisler and P. Vonička (Liberec, Czech Republic) and M. Tkoč (Praha, Czech Republic) for enabling me to revise material of the three families under their care or ownership. My thanks are also extended to all who provided me with literature, unpublished information and other advices, namely to K. N. Barber (Sault Ste. Marie, Canada), O. Lonsdale (Ottawa, Canada), M. G. Krivosheina, A. I. Shatalkin (Moscow, Russia) and M. Tkoč (Praha, Czech Republic). I would like particularly to thank P. J. Chandler (Melksham, England) for the linguistic and scientific review of the manuscript. The study was financially supported by the Ministry of Culture of the Czech Republic by institutional financing of long-term conceptual development of the research institution (the Silesian Museum, MK000100595), internal grant of the Silesian Museum No. IGS201607/2016.

\section{References}

B arber K.N. (2006): Strongylophthalmyia pengellyi n. sp., a second species of Nearctic Strongylophthalmyiidae (Diptera) - J. Entomol. Soc. Ont. 137: 81-109.

Barták M. (2001a): Tanypezidae. In Barták M. \& Vaňhara J. (eds): Diptera in an industrially affected region (north-western Bohemia, Bílina and Duchcov environs), II. - Folia Fac. Sci. Nat. Univ. Masaryk. Brun., Biologia 105: 255-257. 
- (2001b): Megamerinidae. In Barták M. \& Vaňhara J. (eds): Diptera in an industrially affected region (northwestern Bohemia, Bílina and Duchcov environs), II. - Folia Fac. Sci. Nat. Univ. Masaryk. Brun., Biologia 105: 259-261.

Barták M. \& Kubík Š. (2005a): Tanypezidae. Pp. 237-238. In Barták M. \& Kubík Š. (eds): Diptera of Podyjí National Park and its Environs. Česká zemědělská univerzita v Praze, Praha, 434 pp.

- (2005b): Megamerinidae. Pp. 238-239. In Barták M. \& Kubík Š. (eds): Diptera of Podyjí National Park and its Environs. Česká zemědělská univerzita v Praze, Praha, 434 pp.

- (2013): Tanypezidae and Megamerinidae (Diptera) of Vráž nr. Písek. Pp. 47-50. In Kubík Š. \& Barták M. (eds): Workshop on biodiversity, Jevany. Česká zemědělská universita v Praze, Praha, 436 pp.

Chandler P.J. (1975): Notes on the British status of three unusual acalypterate flies (Diptera). - Proc. Br. Entomol. Nat. Hist. Soc. 8: 66-72.

Cole J. H. (1981): Strongylophthalmyia ustulata (Zetterstedt) (Diptera: Tanypezidae) new to Britain. -Entomol. Gaz. 32: 47-50.

Czižek K. (1910): Beiträge zur Dipterenfauna Mährens. (III. Nachtrag). - Ztschr. Mähr. Landesmus. 10: $87-$ 112. Also published separately - Mitt. Kom. Naturwiss. Durchforsch. Mährens, Zool. Abt., 16: 1-26.

Foote B.A. (1970): The larvae of Tanypeza longimana (Diptera: Tanypezidae). Annls Entomol. Soc. Am. 63: $235-238$

Iwasa M. (1998): 3.10. Family Strongylophthalmyiidae. Pp. 173-175. In Papp L. \& Darvas B. (eds): Contributions to a Manual of Palaearctic Diptera. Vol. 3., Higher Brachycera. Science Herald, Budapest, 880 pp.

Jedlička L. \& Stloukalová V. (2001): Červený (ekosozologický) zoznam dvojkrídlovcov (Diptera) Slovenska. Red (ecosozological) list of Diptera of Slovakia. Pp. 139-142. In Baláž D., Marhold K. \& Urban P. (eds): Červený zoznam rastlín a živočichov Slovenska. Red list of plants and animals of Slovakia. Ochrana Prírody 20 (Suppl.), Bratislava, 160 pp. (in Slovak).

Kowarz F. (1883): Contributiones ad faunam Comitatum Zepléniensis collections Dris Cornelli Chyzer. - Mag. Orvos. Term. 22: 233-246.

- (1894): Catalogus insectorum faunae bohemicae, II. Hmyz dvoukřídlý (mouchy - Diptera) v Čechách žijící. [Two-winged insects (flies - Diptera) living in Bohemia]. Společnost pro fysiokracii v Čechách, Praha, 42 pp. (in Czech).

Krivosheina N.P. (1981): Novye Palearkticheskie vidy dvukrylykh roda Strongylophthalmyia Hell. (Diptera, Strongylophthalmyiidae). [New Palaearctic species of the genus Strongylophthalmyia Hell. (Diptera, Strongylophthalmyiidae)]. - Entomol. Obozrenie 60(1): 183-186 (in Russian).

Krivosheina N.P., Krivosheina M.G. \& Nartchuk E.P. (1996): Revizija dvukrylykh semeistva Megamerinidae Rossii. Revision of flies of the family Megamerinidae in Russia. - Zool. Zhurnal 75(10): 1517-1524 (in Russian, with English summary).

Landrock K. (1907): Mährische Zweiflügler. - Achter Ber. Lehrerkl. Naturk. Brünn 1906: 50-71.

Lonsdale O. (2013): Review of the families Tanypezidae and Strongylophthalmyiidae, with a revision of Neotanypeza Hendel (Diptera: Schizophora). - Smithsonian Contr. Zool. 641: 1-60.

- (2014): World catalogue of the family Tanypezidae (Diptera: Schizophora). - Zootaxa 3857(3): 412-422.

Mamaev B.M., Krivosheina N.P. \& Pototskaya V.A. (1977): [Key to larvae of predatory entomophages of tree trunks pests] Moscow, 392 pp. (in Russian).

Martinek V. (1967): Neue Erkenntnisse über Verbreitung einiger zoogeographisch interessanten Arten der Dipterenfamilien Heleomyzidae, Psilidae und Otitidae in Böhmen und Mähren. Pp. 177-181. In Tesař Z. (ed.): II. Entomologisches Symposium über die Probleme der faunistischen und entomogeographischen Erforschung der Tschechoslowakei und Mitteleuropas, Opava 21.-23.IX.1966, Slezské museum, Opava, 374 pp.

- (1979): Druhy čeledí Psilidae a Megamerinidae (Diptera) zastoupené ve sbírkách Moravského muzea v Brně. Species of families Psilidae and Megamerinidae (Diptera) represented in the collections of the Moravian Museum in Brno - Čas. Mor. Muz., Vědy př́r. 64: 103-113 (in Czech with English summary).

- (1985a): Př́íspěvek k poznání rozšíření některých dvoukřídlých (Diptera - Acalyptrata) na jižní Moravě. Contribution to the knowledge of the distribution of some Diptera - Acalyptrata in southern Moravia. Acta Sci. Nat. Mus. Mor. Occid. 1: 41-59 (in Czech with English summary).

- (1985b): Further new species of Diptera (group Acalyptrata) on the territory of Czechoslovakia. - Biológia (Bratislava) 40(6): 625-632.

- (1989): Rozšíření některých méně známých dvoukřídlých (Diptera - Acalyptrata) ve středních Čechách. The distribution of some less known Diptera - Acalyptrata in Central Bohemia. - Bohemia Centr. 18: 161-188 (in Czech, with English summary).

Ozerov A. (2013): Megamerinidae. In Pape T. \& Beuk P. (ed.): Fauna Europaea: Diptera, Brachycera. Fauna Europaea version 2.6.2, http://fauna.naturkundemuseum-berlin.de/ 
Palaczyk A., Klasa A. \& Słowińska-Krysiak I. (2013): The family Strongylophthalmyiidae of Poland with catalog of European species (Insecta: Diptera). - Genus 24: 425-438

Pape T. \& Beuk P. (2013): Strongylophthalmyiidae. In Pape T. \& Beuk P. (ed.): Fauna Europaea: Diptera, Brachycera. Fauna Europaea version 2.6.2, http://fauna.naturkundemuseum-berlin.de/

Roháček J. (1985): New and/or interesting records of Diptera Acalyptrata (Strongylophthalmyiidae, Megamerinidae, Chamaemyiidae, Trixoscelididae, Chyromyidae, Anthomyzidae, Asteiidae, Milichiidae, Carnidae) from Czechoslovakia. - Časopis Slezského Muzea, Opava (A) 34: 193-201.

- (1986a): Čel'ad' Tanypezidae. P. 125. In Čepelák J. (ed.): Diptera Slovenska II. Veda, Bratislava, 435 pp. (in Slovak)

- (1986a): Čel'ad’ Megamerinidae. P. 137. In Čepelák J. (ed.): Diptera Slovenska II. Veda, Bratislava, 435 pp. (in Slovak).

- (1987): Druhý doplněk k faunistice Diptera Acalyptrata v Československu (Pseudopomyzidae, Strongylophthalmyiidae, Chamaemyiidae, Anthomyzidae, Aulacigastridae, Periscelididae, Carnidae, Milichiidae). Second supplement to the acalyptrate Diptera fauna (Pseudopomyzidae, Strongylophthalmyiidae, Chamaemyiidae, Anthomyzidae, Aulacigastridae, Periscelididae, Carnidae, Milichiidae) of Czechoslovakia. Časopis Slezského Muzea, Opava (A) 36: 97-108 (in Czech, with English summary).

- (1995a): Strongylophthalmyiidae. P. 119. In Roháček J., Starý J., Martinovský J. \& Vála M. (eds): Diptera Bukovských vrchov. Diptera of the Bukovské Hills. SAŽP - Správa CHKO a BR Východné Karpaty, Humenné, 232 pp. (in Slovak, with English summary).

- (1995b): Megamerinidae. P. 120. In Roháček J., Starý J., Martinovský J. \& Vála M. (eds): Diptera Bukovských vrchov. Diptera of the Bukovské Hills. SAŽP - Správa CHKO a BR Východné Karpaty, Humenné, 232 pp. (in Slovak, with English summary).

- (1995c): Third supplement to the acalyptrate Diptera fauna of the Czech Republic and Slovakia. Megamerinidae. - Casopis Slezského zemského Muzea, Opava (A) 44: 171-174.

- (1998): 3.9. Family Tanypezidae. Pp. 165-171. In Papp L. \& Darvas B. (eds): Contributions to a Manual of Palaearctic Diptera. Vol. 3., Higher Brachycera. Science Herald, Budapest, 880 pp.

- (1999): Micropezidae, Tanypezidae, Strongylophthalmyiidae, Megamerinidae. In Rozkošný R. \& Van̆hara J. (eds): Diptera of the Pálava Biosphere Reserve of UNESCO, II. - Folia Facultatis Scientiarum Naturalium Universitatis Masarykianae Brunensis, Biologia 100: 231-234.

- (2005a): Tanypezidae. P. 309. In Farkač J., Král D. \& Škorpík M. (eds): Červený seznam ohrožených druhů České republiky. Bezobratlí. Red list of threatened species in the Czech Republic. Invertebrates. Agentura ochrany př́rody a krajiny České republiky, Praha, 760 pp.

- (2005b): Megamerinidae. P. 310. In Farkač J., Král D. \& Škorpík M. (eds): Červený seznam ohrožených druhů České republiky. Bezobratlí. Red list of threatened species in the Czech Republic. Invertebrates. Agentura ochrany př́rody a krajiny České republiky, Praha, 760 pp.

- (2009a): Strongylophthalmyiidae. Pp. 185-186. In Roháček J. \& Ševčík J. (eds): Diptera of the Pol’ana Protected Landscape Area - Biosphere Reserve (Central Slovakia). SNC SR, Administration of the PLA-BR Pol'ana, Zvolen, 340 pp.

- (2009b): Megamerinidae. Pp. 188-189. In Roháček J. \& Ševčík J. (eds): Diptera of the Pol’ana Protected Landscape Area - Biosphere Reserve (Central Slovakia). SNC SR, Administration of the PLA-BR Pol'ana, Zvolen, 340 pp.

- (2009c): Megamerinidae Hendel, 1913. In Jedlička L., Kúdela M. \& Stloukalová V. (eds): Checklist of Diptera of the Czech Republic and Slovakia. Electronic version 2. http://www.edvis.sk/diptera2009/families/ megamerinidae.htm, + CD-ROM: ISBN 978-80-969629-4-5.

- (2009d): Strongylophthalmyiidae Hendel, 1917. In Jedlička L., Kúdela M. \& Stloukalová V. (eds): Checklist of Diptera of the Czech Republic and Slovakia. Electronic version 2. http://www.edvis.sk/diptera2009/families/strongylophthalmyiidae.htm + CD-ROM: ISBN 978-80-969629-4-5.

- (2009e): Tanypezidae Andersen, 1876. In Jedlička L., Kúdela M. \& Stloukalová V. (eds): Checklist of Diptera of the Czech Republic and Slovakia. Electronic version 2. http://www.edvis.sk/diptera2009/families/ tanypezidae.htm + CD-ROM: ISBN 978-80-969629-4-5.

- (2013): Tanypezidae. In Pape T. \& Beuk P. (ed.): Fauna Europaea: Diptera, Brachycera. Fauna Europaea version 2.6.2, http://fauna.naturkundemuseum-berlin.de/

Roháček J. \& Barták M. (1999): Sphaeroceridae (Diptera) of peat-bogs in the Šumava Mts. (SW Bohemia, Czech Republic). - Časopis Slezského zemského Muzea, Opava (A) 48: 9-32.

Rotheray G.E. (2015): New records of Strongylophthalmyia ustulata (Zetterstedt) (Diptera, Strongylophthalmyiidae). - Dipterists Digest (Second Series) 22: 58.

Rotheray G.E. \& Robertson D.M. (1998): Breeding habits and early stages of seven saproxylic acalypterates. - Dipterists Digest (Second Series) 5: 96-107.

Rozkošný \& Vaňhara J. (1992): Diptera (Brachycera) of the agricultural landscape in southern Moravia. Acta Sci. Nat. Brno, 26(4): 1-64. 
- (1993): Diptera (Brachycera) of a forest steppe near Brno (Hády hill). - Acta Sci. Nat. Brno, 27(2-3): 1-72.

- (1994): Diptera (Brachycera) of the agricultural landscape in southern Moravia: faunistic and biogeographical aspects. - Scripta Fac. Sci. Nat. Univ. Masaryk. Brun. Biologia 22-23 (1992-1993): 85-97.

Shatalkin A.I. (1993): K systematike mukh semeistva Strongylophthalmyiidae (Diptera). On the taxonomy of the flies of the family Strongylophthalmyiidae (Diptera). - Zool. Zhurn. 72(10): 124-131 (in Russian, with English summary).

Soós Á. (1946): Die acalypteren Musciden des Karpatenbecken. III. - Fragm. Faun. Hung. 9: 2-10.

Van̆hara J. (1981): Lowland forest Diptera (Brachycera, Cyclorrhapha). - Acta Sci. Nat. Brno 15(1): 1-32.

- (1986): Impact of man-made moisture changes on floodplain forest Diptera. - Acta Sci. Nat. Brno, 20(7): 135.

Vimmer A. (1913): Seznam českého hmyzu dvoukřídlého. (Catalogus Dipterorum) [Checklist of the Czech two-winged insects (Catalogus Dipterorum)]. Entomologické př́ručky VIII. Česká společnost entomologická, Praha, iii + 99 pp. (in Czech)

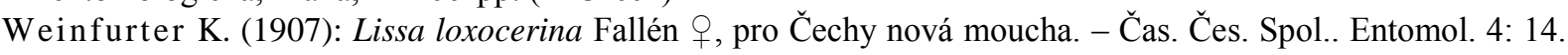
(in Czech).

\section{Strongylophthalmyiidae, Tanypezidae and Megamerinidae (Diptera) v České republice a na Slovensku: současný stav poznání}

Je podán přehled výskytu zástupců akalyptrátních čeledí Strongylophthalmyiidae, Tanypezidae a Megamerinidae v České republice a na Slovensku založený na vyhodnocení publikovaných údajů a dat z nálezů získaných v poslední době. Strongylophthalmyia pictipes Frey, 1935 (Strongylophthalmyiidae) je novým druhem pro území České republiky. Jeho nález v Jizerských horách je teprve druhým ve střední Evropě a současně představuje nejjihozápadnější výskyt $\mathrm{v}$ rámci areálu rozšíření tohoto boreomontánního druhu. Kromě tohoto vzácného druhu jsou pojednány i ostatní tři druhy těchto čeledí známé ve střední Evropě, viz Strongylophthalmyia ustulata (Zetterstedt, 1847) (Strongylophthalmyiidae), Tanypeza longimana Fallén, 1820 (Tanypezidae) a Megamerina dolium (Fabricius, 1805) (Megamerinidae) a podrobně je diskutována jejich bionomie, rozšíření, faunistika v České republice a na Slovensku a také význam pro ochranu přírody s vyhodnocením stupně jejich ohrožení.

Author's address: Jindřich Roháček, Slezské zemské muzeum, Nádražní okruh 31, CZ - 74601 Opava, Czech Republic; e-mail: rohacek@szm.cz 